\title{
Identification of a small molecule activator of novel PKCs for promoting glucose-dependent insulin secretion
}

\author{
Shuai Han ${ }^{1, *}$, Heling Pan $^{2, *}$, Jianhua Zhang ${ }^{1}$, Li Tan$^{2}$, Dawei Ma ${ }^{2}$, Junying Yuan ${ }^{3}$, Jia-Rui $\mathrm{Wu}^{1,4}$ \\ ${ }^{I}$ Key Laboratory of Systems Biology, Institute of Biochemistry and Cell Biology, Shanghai Institutes for Biological Sciences, \\ Chinese Academy of Sciences, Shanghai 200031, China; ${ }^{2}$ Shanghai Institute of Organic Chemistry, Chinese Academy of Sci- \\ ences, Shanghai 200032, China; ${ }^{3}$ Department of Cell Biology, Harvard Medical School, Boston, MA 02115, USA; ${ }^{4}$ Hefei National \\ Laboratory for Physical Sciences at Microscale and School of Life Sciences, University of Science \& Technology of China, Hefei, \\ 230027, China
}

Using an image-based screen for small molecules that can affect Golgi morphology, we identify a small molecule, Sioc145, which can enlarge the Golgi compartments and promote protein secretion. More importantly, Sioc145 potentiates insulin secretion in a glucose-dependent manner. We show that Sioc145 selectively activates novel protein kinase Cs (nPKCs; $\delta$ and $\varepsilon$ ) but not conventional PKCs (cPKCs; $\alpha, \beta I$ and $\beta I I)$ in INS-1E insulinoma cells. In contrast, PMA, a non-selective activator of cPKCs and nPKCs, promotes insulin secretion independent of glucose concentrations. Furthermore, we demonstrate that Sioc145 and PMA show differential abilities in depolarizing the cell membrane, and suggest that Sioc145 promotes insulin secretion in the amplifying pathway downstream of $K_{\text {ATP }}$ channels. In pancreatic islets, the treatment with Sioc145 enhances the second phase of insulin secretion. Increased insulin granules close to the plasma membrane are observed after Sioc145 treatment. Finally, the administration of Sioc145 to diabetic GK rats increases their serum insulin levels and improves glucose tolerance. Collectively, our studies identify Sioc145 as a novel glucose-dependent insulinotropic compound via selectively activating nPKCs.

Keywords: PKC; insulin secretion; glucose dependency; Golgi

Cell Research (2011) 21:588-599. doi:10.1038/cr.2010.137; published online 28 September 2010

\section{Introduction}

Regulation of insulin secretion plays a critical role in glucose homeostasis. Two signaling pathways have been identified that play major roles in mediating glucose-stimulated insulin secretion (GSIS), the triggering pathway and the amplifying pathway $[1,2]$. Under physiological conditions, the triggering pathway plays a primary role in determining whether insulin is secreted

\footnotetext{
*These two authors contributed equally to this work.

Correspondence: Jia-Rui $\mathrm{Wu}^{\mathrm{a}}$, Junying Yuan ${ }^{\mathrm{b}}$

${ }^{\mathrm{a}}$ Tel: +86-21-54921128

E-mail:wujr@sibs.ac.cn

${ }^{b}$ E-mail: jyuan@hms.harvard.edu

Abbreviations: CHX (cycloheximide); DZX (diazoxide); GFX (GF109203X); GSIS (glucose-stimulated insulin secretion); PKC (protein kinase C); SEAP (secretory form of the human placental alkaline phosphatase)

Received 18 August 2010; revised 22 August 2010; accepted 28 August 2010; published online 28 September 2010
}

[3]; whereas the amplifying pathway, manifesting itself only after the triggering signal has been produced, serves to optimize the secretory response $[2,4]$. The threshold concentration of glucose for activating the triggering pathway is much higher than that required for the amplifying pathway $[2,4]$. The hierarchy between the two pathways ensures that no insulin is inappropriately secreted under the conditions of low glucose concentrations. The current insulinotropic therapy using sulfonylureas alters the hierarchy and thus suffers a mechanismbased side effect of inducing hypoglycemia [2]. Selective activation of regulators distal to the production of triggering signals is believed to be an important strategy for enhancing glucose-dependent insulin secretion.

Several protein kinase C (PKC) isoforms are expressed in pancreatic $\beta$-cells and have been implicated in the regulation of GSIS [5-8]. Different PKC isoforms are speculated to play different roles, but the exact functions of individual PKC isoforms in regulating insulin secretion are still controversial $[9,10]$. PMA, a non-selective 
phorbol ester activator of both conventional (c) PKCs ( $\alpha$, $\beta I, \beta I I$ and $\gamma)$ and novel (n) PKCs $(\delta, \varepsilon, \eta / 1$ and $\theta)$, stimulates insulin secretion independent of glucose concentrations [6]. As far as we know, no selective PKC activator that is capable of regulating glucose-dependent insulin secretion has been reported.

Recently, we have developed an image-based assay using YFP-tagged p58 as a Golgi marker to identify small molecules as regulators of protein secretion [11]. Using this assay, we isolated a small molecule, Sioc145, which can enlarge the Golgi compartments and promote protein secretion. We show that in pancreatic islets and a selected $\beta$-cell line, Sioc145 potentiates insulin secretion in a glucose-dependent manner. Furthermore, we show that Sioc145 selectively activates nPKCs but not cPKCs, and provide evidence that acute $\mathrm{nPKCs}$ activation potentiates GSIS in the amplifying pathway downstream of $\mathrm{K}_{\mathrm{ATP}}$ channels.

\section{Results}

Identification of Sioc145 as a modulator of Golgi morphology

Since the Golgi plays a central role in mediating protein modification and secretion, we designed an imagebased screen to isolate small molecules that affect the morphology of the Golgi [11]. H4 human glioblastoma cell line was made to stably express a p58-YFP fusion protein (H4-p58-YFP), in which p58, a cargo receptor involved in transporting proteins from endoplasmic reticulum to the Golgi complex, was used as a marker for the vesicular tubular clusters and the cis-Golgi [12].

Using H4-p58-YFP cells and fluorescent microscopy, we screened for compounds that could affect the fluorescent signal of p58-YFP in the SIOC Chemical Library containing 200 small molecule compounds that are speculated to have high bioactivity $[13,14]$. p58-YFP normally appeared as peripheral punctate structures close to the cis-Golgi (Figure 1A). Sioc145, a derivative of benzolactam-V8 designed to be a PKC activator $[13,14]$, can significantly enhance the fluorescent signal of p58YFP (Figure 1A). Interestingly, this effect of Sioc145 is fully reversible: the levels of size and intensity of p58YFP signal returned to normal after the Sioc145-treated $\mathrm{H} 4$ cells were cultured in media without Sioc 145 for $24 \mathrm{~h}$.

We measured the images for the size and intensity of p58-YFP signal using high-throughput fluorescent microscopy. The intensity and area of p58-YFP spots in Sioc145-treated $\mathrm{H} 4$ cells were enlarged in a dose- and time-dependent manner with an $\mathrm{EC}_{50} \approx 0.78 \mu \mathrm{M}$ (Figure $1 \mathrm{~B}$ and $1 \mathrm{C}$ ). The maximum increase in the area of $\mathrm{p} 58$ YFP was up to 7-8 times than that of the negative con- trol. We also analyzed the effect of Sioc145 on cell viability. Treatment with up to $25 \mu \mathrm{M}$ of Sioc 145 for $24 \mathrm{~h}$ had no obvious effect on cell survival, whereas the cells died after treatment with $50 \mu \mathrm{M}$ Sioc 145 for $24 \mathrm{~h}$ (Supplementary information, Figure S1). Thus, the difference between $\mathrm{EC}_{50}$ and $\mathrm{LD}_{50}$ of Sioc 145 on $\mathrm{H} 4$ cells is at least 25 -fold.

We conducted a structure activity relationship (SAR) study to analyze the structural requirement for the effect of Sioc145 in enhancing p58-YFP signal. We found that Sioc111, a close diastereoisomer analog of Sioc145 (Figure 1D), had a significantly reduced effect on the fluorescent signal of p58-YFP (Figure 1E), suggesting a stringent SAR relationship. Consistent with the role of PKCs in regulating the Golgi morphology, PMA treatment also significantly increased the p58-YFP signal (Figure 1E).

To test whether the enhancement of p58-YFP signal by Sioc145 relies on protein synthesis, we treated H4p58-YFP cells with cycloheximide (CHX), an inhibitor of protein biosynthesis. Treatment with CHX alone did not have any obvious effect on the signal marked by p58-YFP in control cells (Figure 1F and Supplementary information, Figure S2). Furthermore, the increases in size and intensity of p58-YFP signal in Sioc145-treated cells were not reduced in the presence of CHX. Thus, the enhancing effect of Sioc145 on p58-YFP signal is independent of protein synthesis.

\section{Effect of Sioc145 on morphology and structure of the} Golgi

To further explore the effect of Sioc145 on the Golgi, we examined the Golgi morphology in parental $\mathrm{H} 4$ cells by immunofluorescence using an antibody against a Golgi matrix protein GM130, which is peripherally associated with the cis-Golgi compartment [15]. As shown in Figure 2A, the cis-Golgi compartment marked by antiGM130 in H4 cells treated with Sioc145 grew larger in a time-dependent manner. A significant increase in the Golgi sizes was also observed for the Sioc145-treated $\mathrm{H} 4$ cells expressing CFP-tagged GalT, which is a marker for trans-Golgi (Supplementary information, Figure S3). These data suggest that Sioc145 has a strong enlargement effect on the size of both the cis- and trans-Golgi.

We also used electron microscopy to assess the effect of Sioc145 on the ultra-structure of the Golgi stacks and vesicles. Comparing to that of the untreated cells, the numbers of Golgi stacks and vesicles were increased significantly in Sioc145-treated H4 cells (Figure 2B). Furthermore, a large number of vesicles with big granules were found around the Golgi stacks, suggesting that Sioc145 not only enlarges the Golgi size but may also promote vesicular transport. 
A

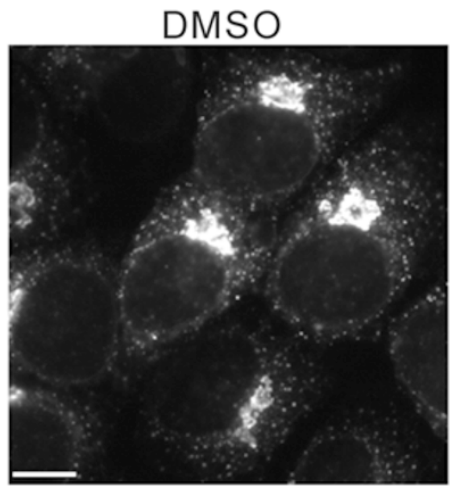

B

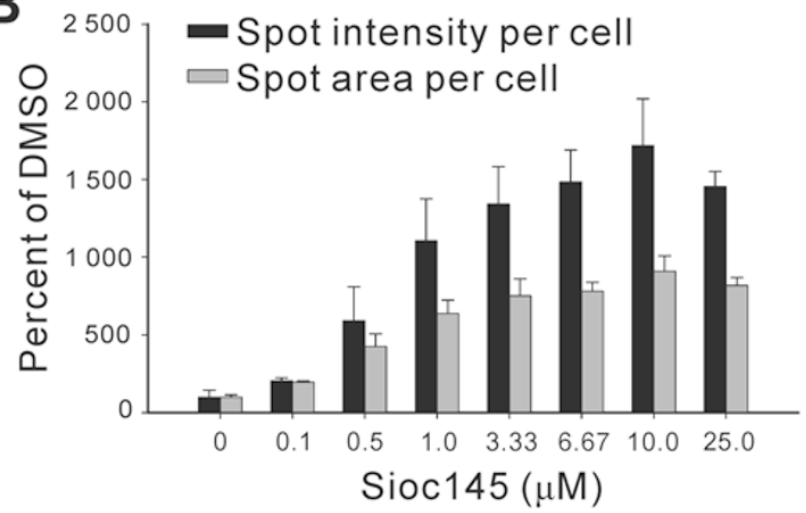

Sioc145

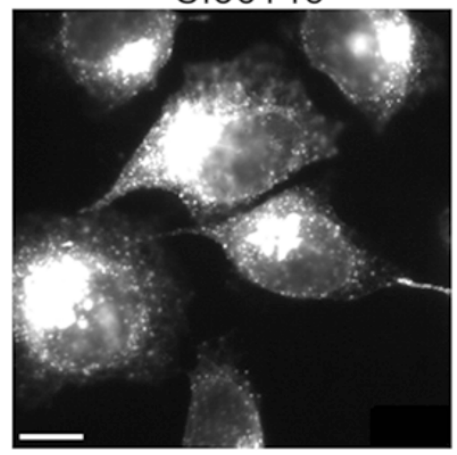

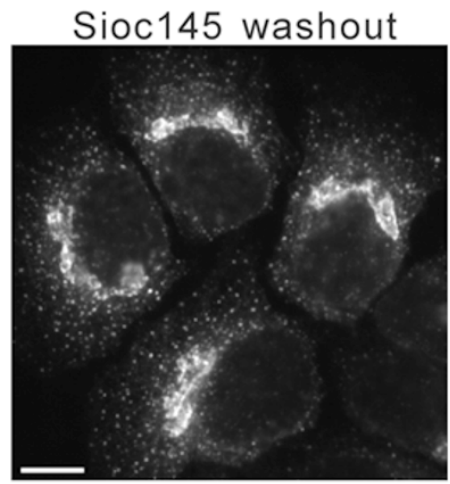

C

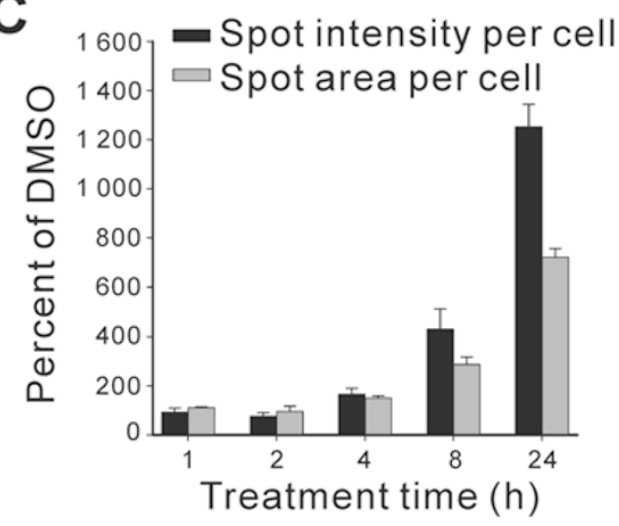

D<smiles>CC(C)[C@H]1C(=O)N[C@H](O)Cc2c(ccc(C#CC[AsH2+])c2O)N1C</smiles><smiles>[Z17]C#CC#Cc1ccc2c(c1O)C[C@H](CO)NC(=O)C(C(C)C)N2C</smiles>

Sioc111 (2)
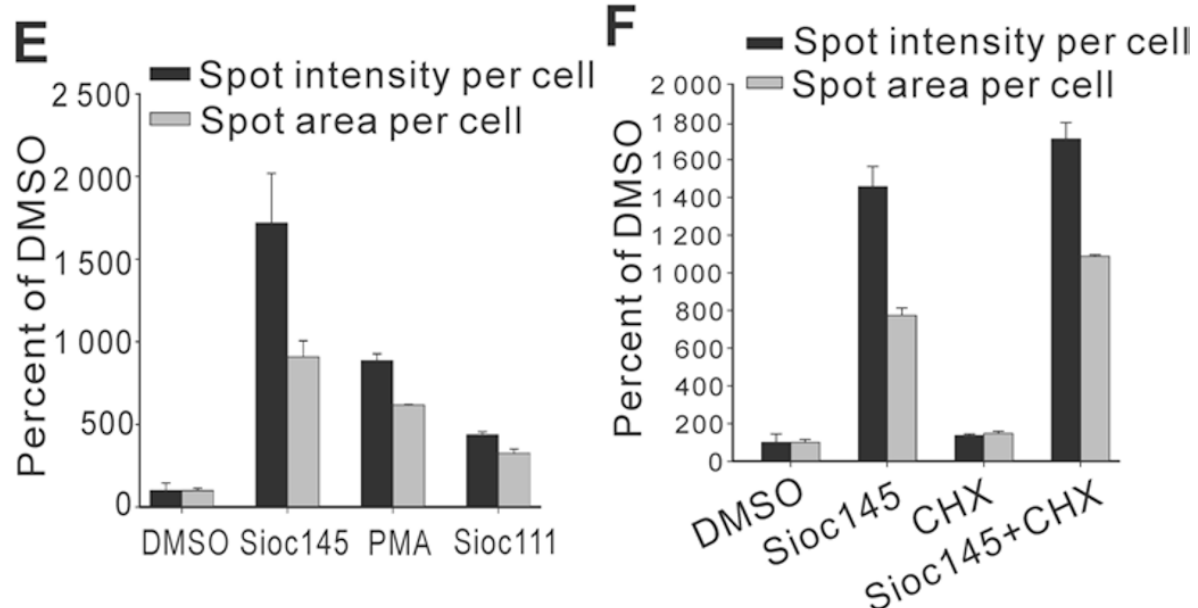

Figure 1 Sioc145 enhances the signal of p58-YFP in H4 cells. (A) H4-p58-YFP cells were treated with DMSO or $5 \mu \mathrm{M}$ Sioc145 for $24 \mathrm{~h}$ or then exchanged with fresh medium without Sioc145 for an additional $24 \mathrm{~h}$. Images were analyzed for spots' intensity and area per cell. Scale bar, $10 \mu \mathrm{m}$. (B) Dose-response of Sioc145 in H4-p58-YFP cells treated for $24 \mathrm{~h}$. (C) Time course response of $5 \mu \mathrm{M}$ Sioc145 in H4-p58-YFP cells. (D) Chemical structures of Sioc145 and Sioc111. (E) p58-YFP signal in cells treated with DMSO, $5 \mu \mathrm{M}$ Sioc145, $5 \mu \mathrm{M}$ Sioc111 or $100 \mathrm{ng} / \mathrm{ml}$ PMA. (F) p58-YFP signal in cells treated with DMSO, $5 \mu \mathrm{M}$ Sioc145, $10 \mu \mathrm{g} / \mathrm{ml} \mathrm{CHX}$ alone or CHX together with $5 \mu \mathrm{M}$ Sioc145 for $24 \mathrm{~h}$. All graphics represent means \pm SD obtained from three independent experiments.

Sioc145 promotes SEAP secretion in a PKC-dependent manner

Based on the above results, we surmise that Sioc145 may be able to promote protein secretion. To examine this hypothesis, we established a stable $\mathrm{H} 4$ cell line that expresses a secretory form of the human placental alka- 


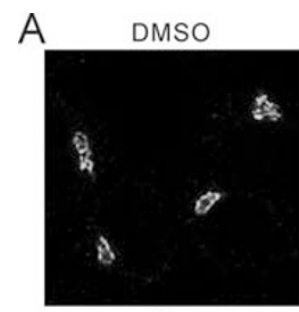

$8 \mathrm{~h}$

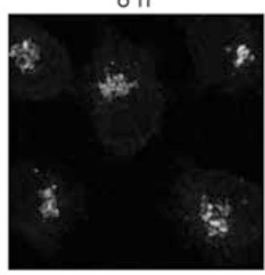

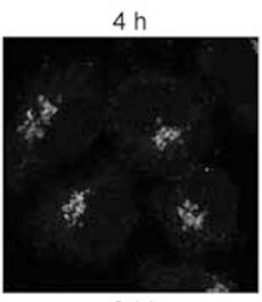

$24 \mathrm{~h}$

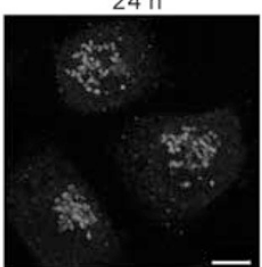

B
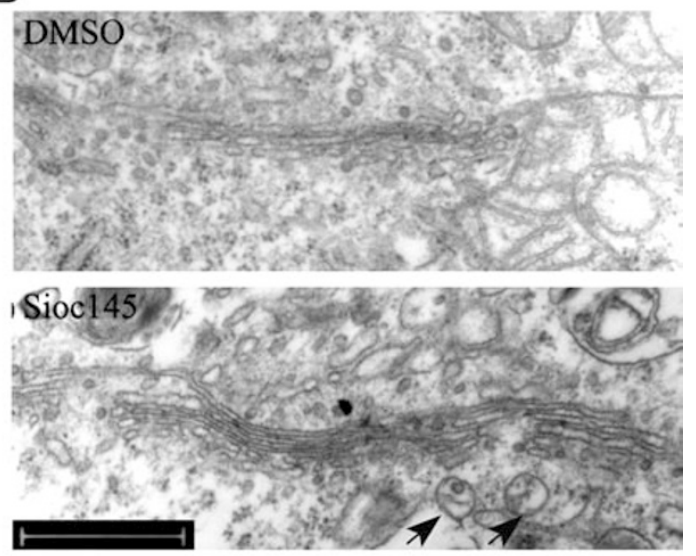

Figure 2 Effect of Sioc145 on the morphology and structure of the Golgi. (A) Immunofluorescence images of H4 cells treated with DMSO, $5 \mu \mathrm{M}$ Sioc145 for $4 \mathrm{~h}, 8 \mathrm{~h}$ or $24 \mathrm{~h}$ using GM130 antibody. Scale bar, $10 \mu \mathrm{m}$. (B) Representative electron microscopy images of the Golgi in $\mathrm{H} 4$ cells treated with DMSO or $5 \mu \mathrm{M}$ Sioc145 for $24 \mathrm{~h}$. Arrows indicate the representatives of big secretory vesicles. Scale bar, $500 \mathrm{~nm}$.

line phosphatase (SEAP). Secretion of SEAP can be used as an assay to determine the rate of protein secretion $[16,17]$. Using this assay, we found that Sioc145 treatment promoted SEAP secretion in a dose-dependent manner (Figure $3 \mathrm{~A})$. We determined the effective concentration for the half-maximum response $\left(\mathrm{EC}_{50}\right)$ of Sioc145-mediated SEAP secretion to be $0.62 \mu \mathrm{M}$, which is in good agreement with its $\mathrm{EC}_{50}$ in enlarging the Golgi compartment $(0.78 \mu \mathrm{M})$. Consistent with the ability of Sioc 145 in promoting secretion, the intracellular levels of SEAP (endo-
AP) were decreased after the treatment with Sioc145 for $24 \mathrm{~h}$ (Figure 3A and 3B).

To further explore the roles of PKCs in mediating the effects of Sioc145, we employed different PKC activators and inhibitors (Figure $3 \mathrm{C}$ ). Consistent with the role of PKC, the treatment with PMA alone increased SEAP secretion. Rottlerin, Gö6976, Ro318220 and GF109203X (GFX), all of which are PKC inhibitors, had no apparent effect on SEAP secretion when used alone. However, both pan PKC inhibitors, Ro318220 and GFX, signifi-
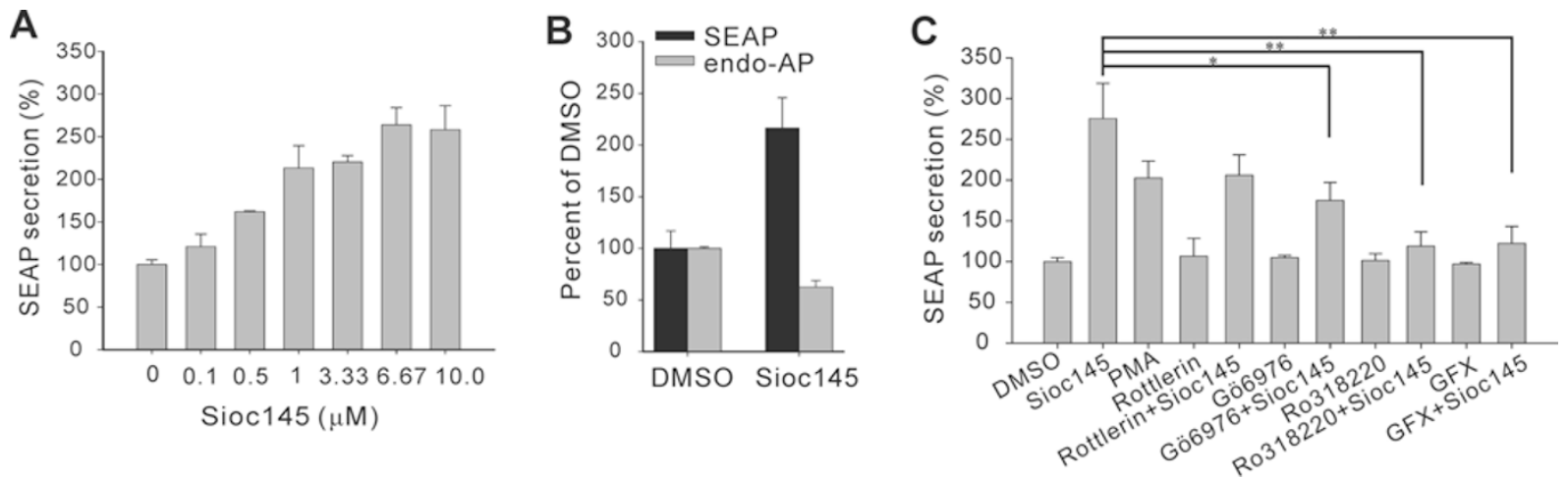

Figure 3 Sioc145 promotes SEAP secretion via a PKC-dependent pathway. (A) Dose-response of Sioc145 in promoting

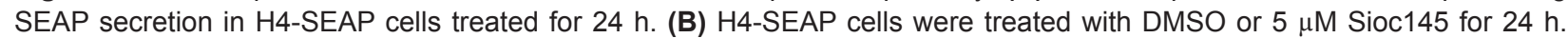
The levels of alkaline phosphatase enzyme in culture medium (SEAP) or total cell lysate (endo-AP) were analyzed. (C) H4SEAP cells were treated with DMSO, $5 \mu \mathrm{M}$ Sioc145 or $100 \mathrm{ng} / \mathrm{ml}$ PMA in the presence or absence of $10 \mu \mathrm{M}$ Rottlerin, $2 \mu \mathrm{M}$ Gö6976, $2 \mu$ M Ro318220 or $2.5 \mu$ M GFX for 24 h as indicated. Secreted SEAP was measured. Data are normalized to that of DMSO-treated cells, which is set as $100 \%$ and error bars represent SD from three independent experiments. $* P<0.05$; $* * P$ $<0.01$. 
cantly inhibited the enhancing effect on SEAP secretion induced by Sioc145. In addition, Gö6976, which inhibits cP$\mathrm{KCs}$, or Rottlerin, which inhibits PKC $\delta$ selectively, partially inhibited the effect of Sioc145 on SEAP secretion. These results suggest that the enhancement of SEAP secretion in $\mathrm{H} 4$ cells by Sioc 145 treatment requires PKC activation.

Sioc145 potentiates insulin secretion in a glucose-dependent manner

To investigate the promoting effect of Sioc145 on secretion in a physiological relevant setting, we examined whether Sioc145 has an insulinotropic effect in rat insulinoma INS-1E cells. We treated INS-1E cells for a short time of 30 min with Sioc145 under the condition of 2.8 $\mathrm{mM}$ (low) or $16.7 \mathrm{mM}$ (high) glucose. The result showed that Sioc145 potentiated high glucose-stimulated insulin secretion in a dose-dependent manner, whereas it did not enhance insulin secretion under the condition of $2.8 \mathrm{mM}$ glucose (Figure 4A). Similar results were also obtained from isolated rat pancreatic islets, although the effect was quantitatively less dramatic than that in INS-1E cells (Figure 4B).

Since a previous report indicated that PMA was an insulinotropic compound without glucose dependency [6], the relationship between glucose concentration and the stimulatory action of Sioc145 was further analyzed in comparison with PMA. Consistent with published results [6], PMA could trigger insulin secretion under conditions of low $(2.8 \mathrm{mM})$ or even no glucose, whereas Sioc145 potentiated insulin secretion only under the conditions of high stimulatory glucose concentrations $(5.6 \mathrm{mM}$ and 16.7 mM; Figure 4C). These data indicate that Sioc145 may promote insulin secretion in a glucose concentration-dependent manner.
Selective activation of $n P K C s$ is required for insulinotropic action of Sioc145

Since the phosphorylation of MARCKS protein has been used as a marker of PKC activation [18], we examined the status of MARCKS phosphorylation in Sioc145treated INS-1E cells. Consistent with the activation of PKCs, the treatment with Sioc145 led to a rapid increase in the phosphorylation of MARCKS within 2 min (Figure 5A). On the other hand, our results showed that Sioc145 increased the phosphorylation of MARCKS under the conditions of both $2.8 \mathrm{mM}$ and $16.7 \mathrm{mM}$ glucose, suggesting that PKC activation mediated by Sioc145 is independent of glucose concentrations.

To explore the mechanism of Sioc145 action on insulin secretion, we analyzed the effect of Sico145 in the presence of different PKC inhibitors. Rottlerin, GFX or Ro318220 were administered to Sioc145-treated INS$1 \mathrm{E}$ cells at $16.7 \mathrm{mM}$ glucose concentration. The results showed that all three inhibitors reduced the insulinotropic effect of Sioc145 to different extents (Figure 5B). In addition, Sioc145 and PMA did not have synergistic effect in potentiating GSIS; and Sioc111 did not have any obvious effect on insulin secretion (Figure 5B), consistent with the results in H4-p58-YFP cells (Figure 1E). These data suggest that Sioc145 potentiated insulin secretion through activating PKC.

To elucidate why Sioc145 and PMA had different glucose dependency in promoting insulin secretion, we analyzed their performances in activating PKC isoforms. Since the translocation of PKCs from cytosol to cell membrane has generally been considered as the hallmark of PKC activation [19, 20], we analyzed the translocation patterns of different PKC isoforms under the Sioc145 or PMA treatments. The immunoblotting
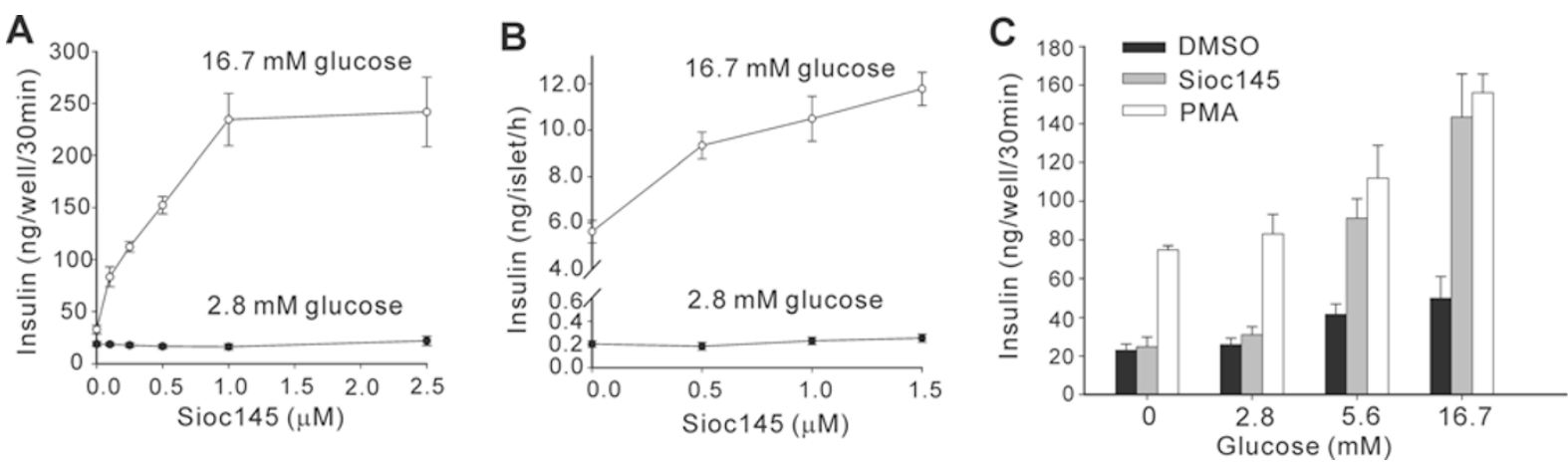

Figure 4 Sioc145 potentiates insulin secretion in a glucose-dependent manner. (A) Insulin secretion from INS-1E cells stimulated with either $2.8 \mathrm{mM}$ or $16.7 \mathrm{mM}$ glucose for $30 \mathrm{~min}$ in the presence of Sioc145 at indicated concentrations. (B) Doseresponse of Sioc145 in rat pancreatic islets stimulated with $2.8 \mathrm{mM}$ or $16.7 \mathrm{mM}$ glucose concentration (see Materials and Methods). (C) Insulin secretion in response to various concentrations of glucose was examined in the presence of $1 \mu \mathrm{M}$ Sioc145 or $0.05 \mu \mathrm{M}$ PMA in INS-1E cells. Error bars represent SEM from three independent experiments. 

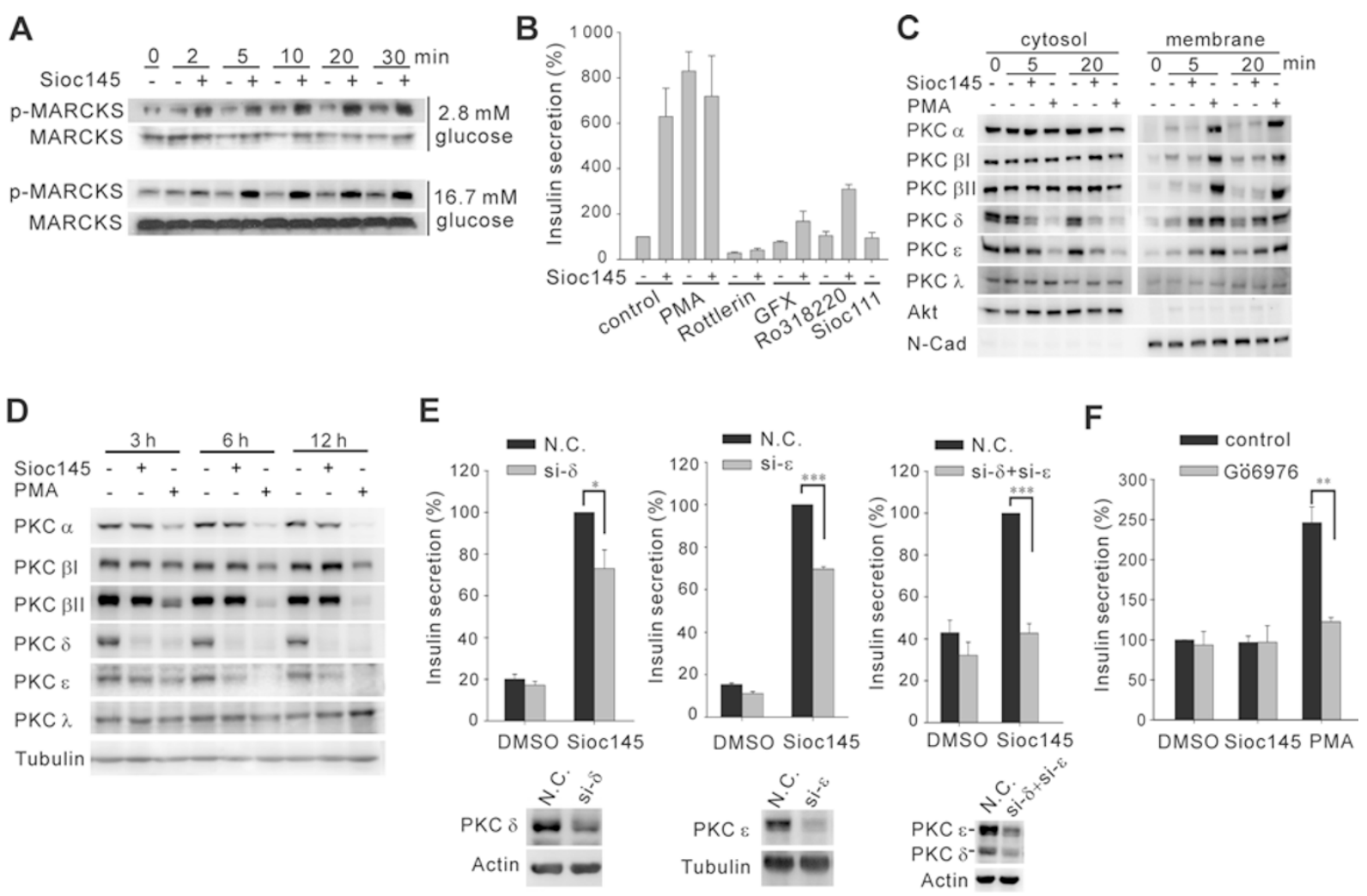

Figure 5 Selective activation of nPKCs is required for insulinotropic action of Sioc145. (A) MARCKS phosphorylation in 2.8 $\mathrm{mM}$ or $16.7 \mathrm{mM}$ glucose was analyzed in INS-1E cells treated with $1 \mu \mathrm{M}$ Sioc145 for indicated time points. (B) $16.7 \mathrm{mM}$ glucose-stimulated insulin secretion from INS-1E cells treated with Sioc145 $(1 \mu \mathrm{M})$ alone or together with indicated compounds: PMA, $0.05 \mu \mathrm{M}$; Rottlerin, $5 \mu \mathrm{M}$; GFX, $2.5 \mu \mathrm{M}$; Ro318220, $2 \mu \mathrm{M}$. Data are normalized to that of DMSO-treated cells which is set as $100 \%$. (C) The translocation of PKC isoforms in INS-1E cells treated with Sioc145 (1 $\mu \mathrm{M})$ or PMA (0.05 $\mu$ M). N-cadherin (N-cad) and Akt were used as membrane and cytosol markers, respectively. (D) Effect of prolonged treatment with Sioc145 (1 $\mu \mathrm{M})$ or PMA $(0.05 \mu \mathrm{M})$ on protein levels of PKC isoforms. (E) Insulin secretion in PKC $\delta$ and/or $\varepsilon$ downregulated cells. Cells transfected with indicated siRNA(s) were stimulated with DMSO or $1 \mu \mathrm{M}$ Sioc145 at $16.7 \mathrm{mM}$ glucose concentration. Insulin secretion from Sioc145-treated control cells (N.C.) were set as 100\%. (F) Gö6976 abolished PMA-induced secretion. INS-1E cells treated with Sioc145 $(1 \mu \mathrm{M})$ or PMA $(0.05 \mu \mathrm{M})$ were co-treated with Gö6976 $(1 \mu \mathrm{M})$ for 30 min in $2.8 \mathrm{mM}$ glucose. Error bars represent SEM from at least three independent experiments. $* P<0.05 ; * * P<0.01 ; * * * P<0.001$.

results showed that the expression of three cPKCs $(\alpha, \beta \mathrm{I}$ and $\beta \mathrm{II})$, two nPKCs $(\delta$ and $\varepsilon)$ and one atypical PKC $(\lambda)$ was detectable in INS-1E cells (Figure 5C). Interestingly, only nPKCs demonstrated membrane translocation in Sioc145-treated cells, whereas the treatment with PMA promoted the membrane translocation of both cPKCs and nPKCs (Figure 5C). Both Sioc145 and PMA did not affect the localization of PKC $\lambda$, which could not bind PMA [21].

It was reported that chronic activation of PKCs resulted in the downregulation of their protein levels [20]. Consistent with the translocation/activation data, nPKCs were downregulated after prolonged Sioc145 treatment, whereas Sioc145 had little effect on the levels of cPKCs, which were significantly downregulated in the PMA- treated cells (Figure 5D). Collectively, the results of membrane translocation and downregulation of PKCs indicate that Sioc145 selectively activates nPKCs in INS$1 \mathrm{E}$ cells.

To further confirm the involvement of nPKCs (PKC $\delta$ and $\varepsilon$ ) in the insulinotropic effect of Sioc145, we conducted RNAi-mediated loss-of-function experiments with chemically synthesized siRNAs (si- $\delta$, si- $\varepsilon$ and si$\varepsilon-2$ ) and lentivirus-mediated transfection of shRNAs (sh- $\delta-1$ and sh- $\delta-2$; Figure 5E and Supplementary information, Figure S4). The results showed that the downregulation of either PKC $\delta$ or PKC $\varepsilon$ by RNAi approach resulted in a significant inhibition of the insulinotropic effect of Sioc145. In addition, the PKC $\delta$ and $\varepsilon$ double knockdown synergistically inhibited Sioc145 insulino- 
tropic effect. Taken together, we conclude that Sioc145 selectively activates PKC $\delta$ and PKC $\varepsilon$, which are both required for its insulinotropic action.

Since cPKCs were activated by PMA but not by Sioc145, we speculated that the activation of $\mathrm{cPKC}$ is required for PMA to trigger insulin secretion under low glucose conditions. The cPKCs inhibitor Gö6976 abolished PMA-triggered insulin secretion under the $2.8 \mathrm{mM}$ glucose condition (Figure 5F), suggesting that $\mathrm{cPKC}$ play a critical role in mediating PMA-induced glucose-independent secretion of insulin. Taken together, the difference in specificity of activating different $\mathrm{PKC}$ isoforms might explain the difference in the glucose dependency between Sioc145 and PMA in promoting insulin secretion.

Cell membrane depolarization is a prerequisite for insulinotropic effect of Sioc145

Cell membrane depolarization achieved via $\mathrm{K}_{\text {АTP }}$ channel inhibition is known as an upstream event for insulin secretion in the triggering pathway [1]. Therefore, we examined the effects of Sioc145 and PMA on cell membrane depolarization. The results showed that the PMA treatment significantly depolarized the cells in the presence of $2.8 \mathrm{mM}$ glucose, which was inhibited by Gö6976, whereas the Sioc145 treatment did not lead to depolarization under the same concentration of glucose (Figure 6A).

We employed diazoxide (DZX), an agonist of $\mathrm{K}_{\text {ATP }}$ channels, to further characterize the role of cell membrane depolarization in the insulinotropic actions of Sioc145 and PMA. The results showed that DZX abolished the insulinotropic effect of Sioc145 under $16.7 \mathrm{mM}$ glucose stimulation, but did not abolish that of PMA in both high and low glucose concentrations (Figure 6B). In the presence of $30 \mathrm{mM} \mathrm{KCl}$, which depolarizes cells [4], Sioc145 enhanced insulin secretion in both $2.8 \mathrm{mM}$ and $16.7 \mathrm{mM}$ glucose concentrations, even in the presence of DZX (Figure 6B). Insulin secretion stimulated by high glucose in the presence of $\mathrm{KCl}$ and DZX reflects the effect of glucose in the amplifying pathway [22]. Taken together, these data indicate that Sioc145 regulates insulin secretion in the amplifying pathway downstream of $\mathrm{K}_{\text {ATP }}$ channels, and that the cell membrane depolarization is a prerequisite for Sioc145 to execute its insulinotropic action.

Characterization of secretion kinetics and insulin granule distributions in Sioc145-treated pancreatic islets

GSIS in pancreatic islets is biphasic: a transient first phase elicited by the triggering pathway, followed by a gradually increasing but sustained second phase elicited by the amplifying pathway acting in synergy with the triggering pathway [1]. We analyzed the kinetics of insulin secretion and the distribution of insulin granules of isolated rat pancreatic islets treated with Sioc145. Interestingly, a pretreatment with Sioc145 significantly enhanced the second phase of GSIS (Figure 7A). Morphologically, the treatment with Sioc145 markedly increased the density of granules close to the plasma membrane (Figure 7B and 7C), while the average density of granules in cytoplasm was not altered significantly (Figure 7D). These results support the above conclusion that Sioc145 does not act on the initial triggering pathway of insulin secretion.

Sioc145 treatment increases plasma insulin levels in diabetic rats

To test the insulinotropic action of Sioc145 in vivo, we analyzed the profile of insulin secretion and glucose
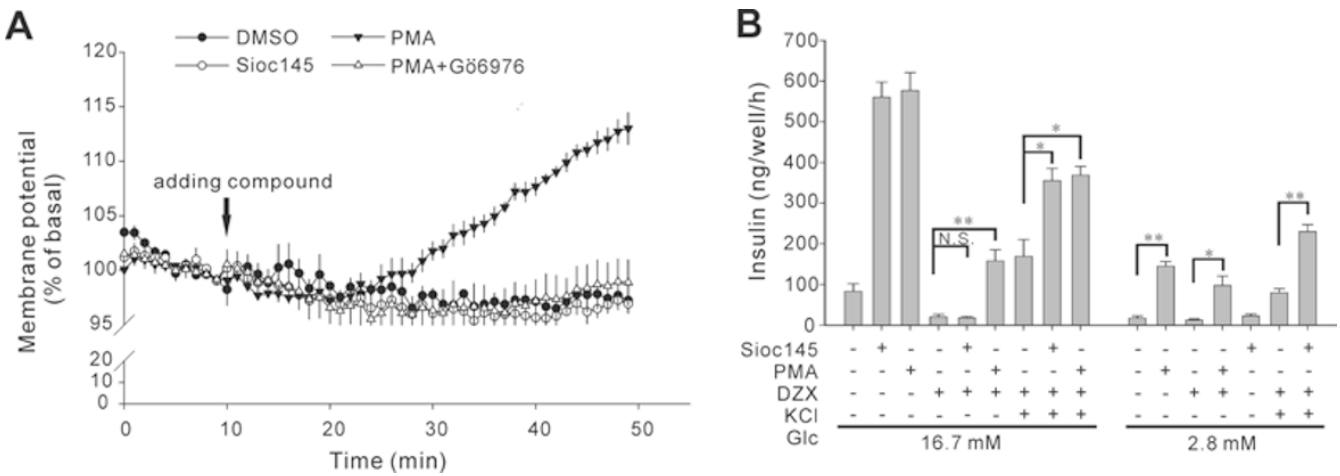

Figure 6 Cell membrane depolarization is a prerequisite for insulinotropic effect of Sioc145. (A) Cell membrane potential was monitored as bisoxonol fluorescence in INS-1E cells stimulated with Sioc145 (1 $\mu \mathrm{M})$, PMA (0.05 $\mu$ M) or PMA plus Gö6976 $(1 \mu \mathrm{M})$, in the presence of $2.8 \mathrm{mM}$ glucose. Arrow indicates the time point when indicated compounds were added. (B) INS$1 \mathrm{E}$ cells were treated with indicated combinations of Sioc145 $(1 \mu \mathrm{M}), \mathrm{PMA}(0.05 \mu \mathrm{M}), \mathrm{DZX}(250 \mu \mathrm{M})$ and $\mathrm{KCl}(30 \mathrm{mM})$, in the presence of $2.8 \mathrm{mM}$ or $16.7 \mathrm{mM}$ glucose for $1 \mathrm{~h}$. Data are means \pm SEM from three independent experiments. N.S., not significant; $* P<0.05 ; * * P<0.01$. 
A

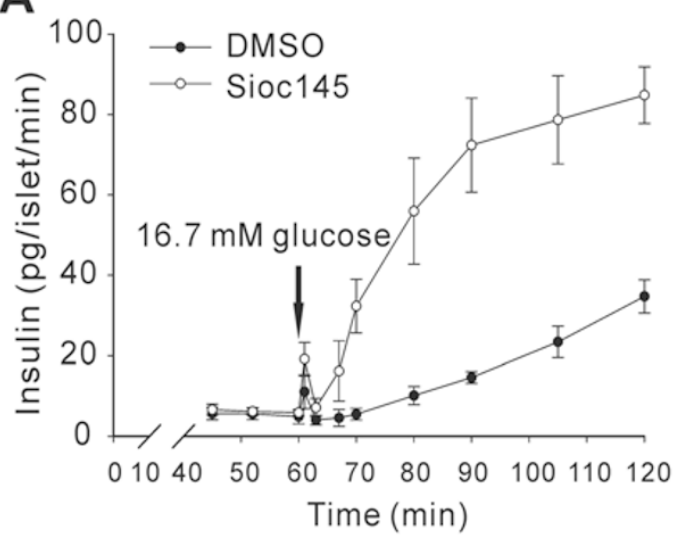

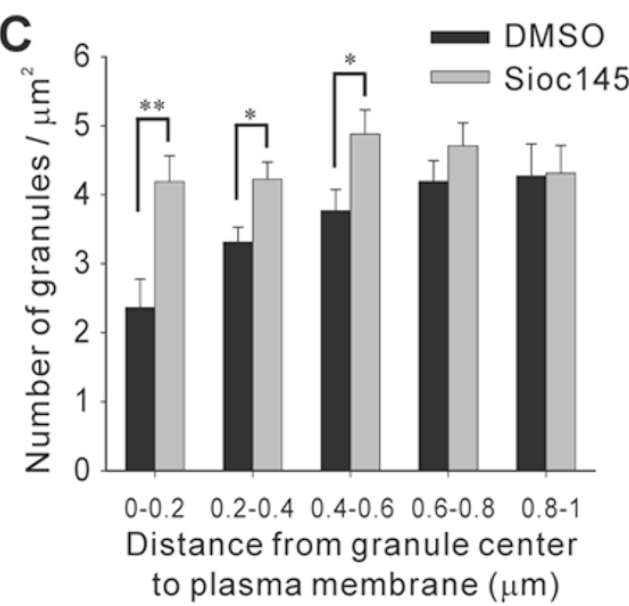

to plasma membrane $(\mu \mathrm{m})$
B

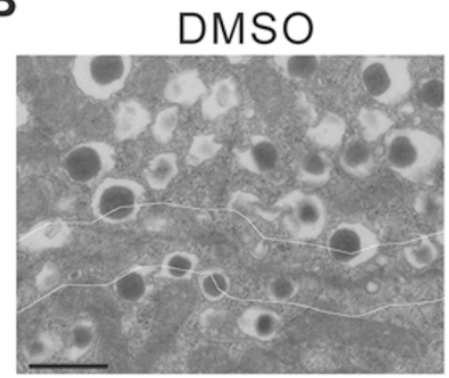

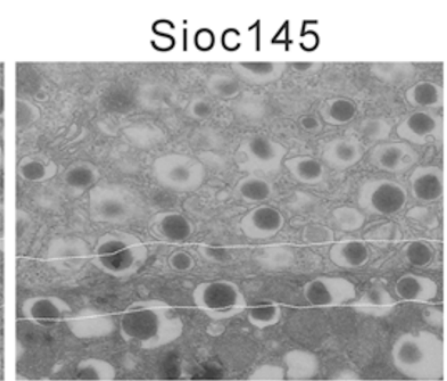

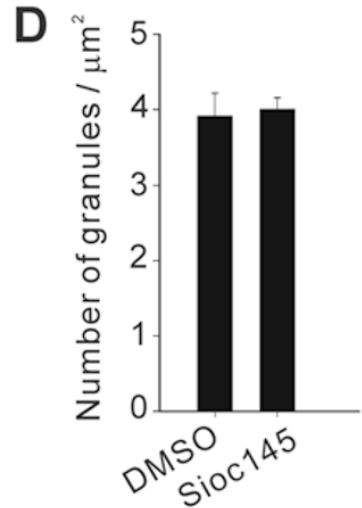

Figure 7 Characterization of secretion kinetics and insulin granule distribution in Sioc145-treated rat pancreatic islets. (A) Rat pancreatic islets pretreated with $5 \mu \mathrm{M}$ Sioc145 or DMSO for 30 min were perifused with $16.7 \mathrm{mM}$ glucose buffer for $1 \mathrm{~h}$, and insulin secretion was measured at indicated time points (see Materials and Methods). (B) Islets were treated with DMSO or $5 \mu \mathrm{M}$ Sioc145 for $30 \mathrm{~min}$, followed by a $60 \mathrm{~min}$ equilibration in $2.8 \mathrm{mM}$ glucose buffer. Representative electron micrographs of islet $\beta$-cell sections are shown. Scale bar, $0.5 \mu \mathrm{m}$. White lines indicate a distance of $0.2 \mu \mathrm{m}$ from the plasma membrane. (C) Density of insulin granules located in $0.2 \mu \mathrm{m}$ concentric shells within the first $1 \mu \mathrm{m}$ area from the plasma membrane. Granules located in the single section were categorized according to their distance from the granule center to the plasma membrane. (D) The average density of granules in cytoplasm. The area of cytoplasm is calculated as the cell area minus the nuclear area. Error bars represent SEM from three independent experiments (A) or 10 individual $\beta$-cells derived from four rats (C, D). ${ }^{*} P<0.05$; ${ }^{*} P<0.01$.

tolerance in Goto-Kakizaki (GK) rats, a model for type 2 diabetes, under Sioc145 treatment. Sioc145 treatment $(0.414 \mathrm{mg} / \mathrm{kg})$ led to a significant increase in the levels of serum insulin in response to glucose administration (Figure $8 \mathrm{~A}$ ), whereas the improvement in glucose tolerance was relatively mild (Figure $8 \mathrm{~B}$ ). In addition, to analyze whether Sioc145 induces hypoglycemia, we treated the fasted Wistar rats with Sioc145 or tolbutamide, a sulfonylurea derivative drug used in the management of type 2 diabetic patients. While the treatment with tolbutamide could further decrease the levels of serum glucose under the fasting condition, Sioc145 had no hypoglycemic effect in fasting rats at the dose of $0.414 \mathrm{mg} / \mathrm{kg}$ during $2 \mathrm{~h}$ of observation (Supplementary information, Figure S5). Thus, consistent with its insulinotropic effect in vitro, Sioc145 treatment could increase plasma insulin levels in vivo in response to glucose loading.

\section{Discussion}

Sioc145 treatment might generate a "competent-forsecretion" state of insulin-secreting cells

In the present study, we show that the action of Sioc145 is downstream of $\mathrm{K}_{\mathrm{ATP}}$ channels and, in contrast to PMA, does not lead to membrane depolarization (Figure 6). Since membrane depolarization is an early triggering 

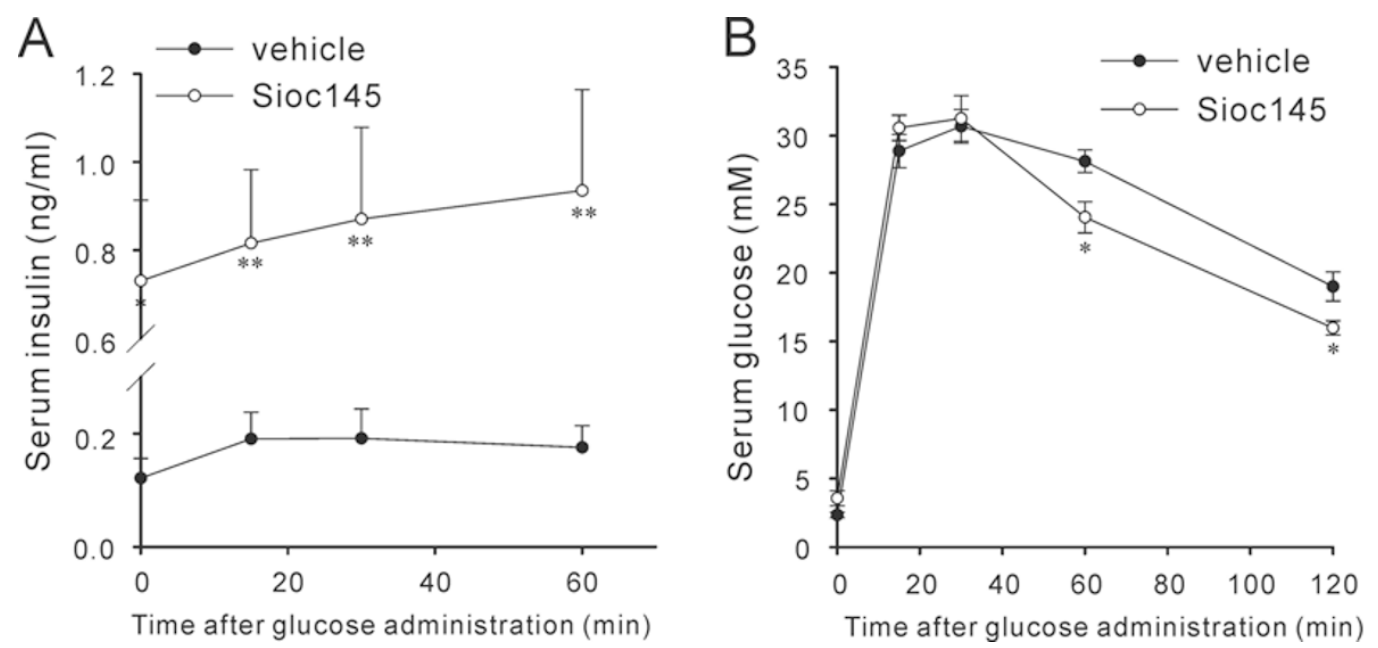

Figure 8 Effect of Sioc145 in diabetic GK rats. Fasted GK rats were administered intraperitoneally with Sioc145 (0.414 mg/ $\mathrm{kg}$ ) or vehicle $2 \mathrm{~h}$ before glucose loading $(2 \mathrm{~g} / \mathrm{kg}$, i.p). Sera were collected before or at indicated time points after glucose administration to measure insulin levels (A) and glucose levels (B). $n \geq 5$. Data shown are means \pm SEM $(* P<0.05 ; * * P<0.01$ vs vehicle; Student's $t$-test).

event for insulin secretion, this observation potentially explains why the treatment with Sioc145 per se does not initiate insulin secretion. In insulin-secreting cells, the ability of Sioc145 to promote insulin secretion requires the presence of high glucose. Since Sioc145 treatment under low glucose conditions activates PKC and increases the number of insulin granules close to the plasma membrane, we speculate that Sioc145 prepares cells to a "competent-for-secretion" state without triggering secretion. Only when cells are depolarized by other stimuli such as glucose, Sioc145 can execute its insulinotropic actions. This hypothesis is supported by our observation that Sioc145 pretreatment sensitized INS-1E cells to respond to later Sioc145-free glucose stimulation (data not shown). This is also consistent with a reported role of $\mathrm{PKC}$ in mediating time-dependent potentiation of insulin secretion [23].

The lack of insulinotropic effect of Sioc145 under low glucose conditions is most probably correlated with its inability to activate cPKCs. cPKCs are required for PMA-induced insulin secretion because Gö6976 could totally inhibit PMA-induced secretion $[6,24]$ and membrane depolarization. In addition, PMA-triggered insulin secretion is significantly inhibited by overexpressing kinase-dead PKC $\alpha$, whereas it is increased by overexpressing wild-type PKC $\alpha$ [24]. The inability of Sioc145 to depolarize the membrane provides direct evidence that PKC $\delta$ and $\varepsilon$ are downstream regulators of insulin secretion.

The amplifying pathway is the major action target of Sioc145. Sioc145 potentiates GSIS in pancreatic islets via enhancing the second phase of secretion. This is consistent with a previous report that islets from PKC $\delta$ knockout mice exhibited normal $\mathrm{Ca}^{2+}$ influx but decreased second phase of GSIS [7]. However, Biden's lab reported recently that $\mathrm{PKC} \varepsilon$ deletion enhances GSIS via the amplifying pathway from mice islets, but this occurs selectively after prolonged lipid exposure $[25,26]$. The seeming discrepancy between this report and our observations implies that prolonged or acute $\mathrm{PKC} \varepsilon$ activation might have different effects on $\beta$-cell function.

Our study suggests that Sioc145 is a novel glucosedependent insulinotropic compound due to its selective activation of nPKCs without activating cPKCs. Previous gain-of-function studies on the mechanisms by which PKC regulates secretion were mostly based on experiments applying PMA as a PKC activator. Since cPKCs and $\mathrm{nPKCs}$ play quite different roles in regulating insulin secretion as suggested by our data, further studies on the actions of Sioc145 in comparison with that of PMA may offer useful clues in understanding different functions of PKC isoforms, and shed light on developing glucose concentration-dependent insulinotropic drugs.

The potential roles of $n P K C$ s in drug targeting and therapeutics of type 2 diabetes

It has been reported that several PKC isoforms are expressed in pancreatic $\beta$-cells [5-8], and different PKC isoforms are speculated to play different roles $[9,10]$. The complexity of in vivo roles of PKCs in insulin secretion was highlighted by the finding that the treatment with either a general PKC inhibitor, bisindolylmaleim- 
ide, or a structurally unrelated PKC inhibitory peptide PKC19-31 restored insulin secretion efficacy in GK rats, whereas the general PKC activator, PMA, did not generate the opposite results [27]. In the present study, Sioc145 treatment significantly increased plasma insulin levels in GK rats (Figure 8A), suggesting that Sioc145 might be able to selectively activate nPKCs in $\beta$-cells in vivo, and the activation of nPKCs in GK rats could promote insulin secretion under the glucose stimulation. This is supported by a previous report that PKC $\delta$ knockout mice demonstrated impaired glucose tolerance due to impaired GSIS [7]. Our results suggest that nPKCs could be used as potential drug targets for regulating glucosedependent insulin secretion.

It should be noted that although the serum insulin levels increased significantly in Sioc145-treated GK rats, the improvement in glucose tolerance was relatively mild (Figure 8B). There are two potential explanations for this result. First, since GK rat is a typical type 2 diabetic model, and these animals had already suffered from insulin resistance besides $\beta$-cell dysfunctions [28], the Sioc145 treatment might not be able to improve insulin sensitivity in the peripheral tissues of GK rats, which led to the relatively minor improvement in glucose tolerance. Second, the Sioc145 treatment, while promoting insulin secretion in pancreas of GK rats, might increase insulin resistance in the muscle or other peripheral tissues, since insulin resistance has been reported to be associated with PKC activation, especially activation of novel PKCs [2932]. It is known that activation of novel PKC isoforms is involved in the impairment of insulin sensitivity induced by free fatty acids (FFAs; reviewed in [33]). In addition, diet containing peptide inhibitors of PKC $\varepsilon$ protected muscle IRS-1 from PKC $\varepsilon$-induced serine phosphorylation, abrogating insulin resistance in a rat model (Psammomys) of type 2 diabetes [34].

Taken together, the complex effects of nPKCs on glucose tolerance of diabetic animal model uncovered in this study and previous ones suggest that a simple activation of nPKCs would not work well as a therapeutic strategy. To do so, one needs to find a way to de-couple the two opposite consequences of nPKC activation, i.e., enhanced insulin secretion and impaired insulin sensitivity. This perhaps could be achieved by more selective activation of particular PKC isoforms or by finding a way to block the inhibitory effect of $\mathrm{nPKC}$ activation on insulin sensitivity.

\section{Materials and Methods}

Plasmids, siRNAs and antibodies

Plasmid expressing p58-YFP was provided by Jennifer
Lippincott-Schwartz (National Institutes of Health, Bethesda, USA). Specific siRNA oligonucleotides against PKC $\delta$ and $\varepsilon$ were synthesized by Shanghai GenePharma Co. or from Ambion Inc. The sequences are as follows: si- $\delta, 5^{\prime}-$ GCAACGCUGCCAUCCA-

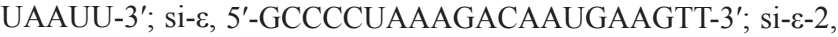
5'-AGCCGAGAAUUAAAACCAATT-3'. To establish stable PKC $\delta$ knockdown cells, a retroviral-based siRNA expression system was used. The target sequences of PKC $\delta$, sh- $\delta-1,5^{\prime}$-GCAGTATTTC CTGGAGGAT-3'; sh- $\delta$-2, 5'-CCTTGAGAACTTCACCTTC-3', were cloned into pSIREN-Retro-Q vector and shuttled into Knockout ${ }^{\mathrm{TM}}$ RNAi Systems (Clontech Laboratories Inc.). A sequence of Shuffle: 5'-AACTAGAGCCACAACTACC-3' was used as control. The following primary antibodies were used: antiGM130 (BD Biosciences), anti-MARCKS (Novus), anti-phosphoMARCKS (Cell Signaling), anti-PKC $\alpha, \delta, \varepsilon, \lambda$ (BD Biosciences), anti-PKC $\beta$ I, $\beta$ II (Santa Cruz Biotechnology), anti-Akt (Cell Signaling), anti-N-Cadherin (BD Biosciences), anti-actin or antitubulin (Sigma).

\section{Cell culture and transfection}

$\mathrm{H} 4$ cells were maintained in DMEM supplemented with $10 \%$ fetal bovine serum, $100 \mathrm{U} / \mathrm{ml}$ penicillin/streptomycin and $2 \mathrm{mM} \mathrm{L}$ glutamine at $37{ }^{\circ} \mathrm{C}, 5 \% \mathrm{CO}_{2}$. Rat insulinoma INS-1E cells, kindly provided by Drs CB Wollheim and P Maechler (University Medical Center, Switzerland), were cultured in RPMI 1640 supplemented with $10 \%$ heat-inactivated fetal bovine serum, $1 \mathrm{mM}$ sodium pyruvate, $50 \mu \mathrm{M}$ 2-mercaptoethanol, $2 \mathrm{mM}$ glutamine, $10 \mathrm{mM}$ HEPES, $100 \mathrm{U} / \mathrm{ml}$ penicillin/streptomycin, as described previously [35]. Transfection was done using Lipofectamine 2000 reagent (Invitrogen) according to the manufacturer's instructions. Stable $\mathrm{H} 4$ cell lines expressing p58-YFP or SEAP were established in the presence of $1 \mathrm{mg} / \mathrm{ml} \mathrm{G418}$ or Zeocin (Invitrogen). Stable knockdown of PKC $\delta$ was obtained by lentivirus-mediated transduction of short hairpins against PKC $\delta$ mRNA and cells were selected with puromycin $(4 \mu \mathrm{g} / \mathrm{ml})$.

\section{Phenotypic screen and image analysis}

H4-p58-YFP cells were plated in 96-well plates at 3000 cells per well, and treated individually with compounds in the SIOC Compounds Library in duplication. The cells were examined using fluorescence microscopy (IX81, Olympus) after incubating with the compounds for $4 \mathrm{~h}, 8 \mathrm{~h}$ and $24 \mathrm{~h}$. Images analysis was performed by high-throughput fluorescent microscopy as described previously [36].

\section{Immunofluorescence and electron microscopy}

Cells cultured on coverslips were washed with PBS, fixed in $3.8 \%$ paraformaldehyde for $20 \mathrm{~min}$ at room temperature. After blocking with $1 \%$ BSA in TBST, cells were incubated with GM130 antibody for $2 \mathrm{~h}$, then with secondary antibody conjugated with Texas Red or FITC (Rockland Immunochemicals) for $1 \mathrm{~h}$. DNA was stained with DAPI $(1 \mu \mathrm{g} / \mathrm{ml})$. Cells were imaged using a confocal microscopy LSM 510 (Carl Zeiss) with a $100 \times$ oil 1.35 NA objective. For electron microscopy, pretreated pancreatic islets or $\mathrm{H} 4$ cells were fixed in $2.5 \%$ glutaraldehyde, dehydrated and embedded. Ultrathin sections $(90 \mathrm{~nm})$ were cut, stained and analyzed by a JEM 1230 electron microscope (JEOL). To determine insulin granule distribution, cell area and distance of the granule center to the plasma membrane were measured using Image-Pro Plus 6.0. 


\section{Measurement of alkaline phosphatase secretion}

The Great EscAPe SEAP assay was used following the manufacturer's instructions (Clontech) using the chemiluminescent substrate CSPD and signal was detected with a plate luminometer.

\section{Pancreatic islets isolation and insulin secretion}

Pancreatic islets were isolated from male Wistar rats (250$300 \mathrm{~g}$ ) by collagenase digestion [37]. In static incubation experiments, size-matched five islets were grouped, and equilibrated with Krebs-Ringer bicarbonate (KRB) buffer containing $2.8 \mathrm{mM}$ glucose for $1 \mathrm{~h}$, then incubated with $2.8 \mathrm{mM}$ glucose buffer in the presence of Sioc145 at indicated concentrations for another $1 \mathrm{~h}$. Finally, the islets were stimulated with $2.8 \mathrm{mM}$ or $16.7 \mathrm{mM}$ glucose buffer in the continuous presence of indicated Sioc145 concentrations for $1 \mathrm{~h}$. Supernatants in the last step were collected for insulin secretion assay. Three independent experiments were carried out in triplicates. KRB buffer is composed of $135 \mathrm{mM} \mathrm{NaCl}$, $3.6 \mathrm{mM} \mathrm{KCl}, 5 \mathrm{mM} \mathrm{NaHCO}, 0.5 \mathrm{mM} \mathrm{NaH}_{2} \mathrm{PO}_{4}, 0.5 \mathrm{mM} \mathrm{MgCl}_{2}$, $1.5 \mathrm{mM} \mathrm{CaCl}_{2}$ and $0.1 \% \mathrm{BSA}, \mathrm{pH}$ 7.4. In perifusion studies, sizematched 50 islets were loaded onto each column immediately after the isolation as described previously [38]. Islets were perifused with KRB buffer at a flow rate of $0.6 \mathrm{ml} / \mathrm{min}$ for $30 \mathrm{~min}$ in the presence of $2.8 \mathrm{mM}$ glucose for equilibration, then with $2.8 \mathrm{mM}$ glucose buffer supplemented with Sioc145 or DMSO for $30 \mathrm{~min}$. Next, the islets were perifused in $2.8 \mathrm{mM}$ glucose buffer for $1 \mathrm{~h}$, finally stimulated with $16.7 \mathrm{mM}$ glucose for $1 \mathrm{~h}$. Perifusate solutions were gassed with $95 \% \mathrm{O}_{2} / 5 \% \mathrm{CO}_{2}$ and maintained at $37{ }^{\circ} \mathrm{C}$.

For insulin secretion from INS-1E cells, the cells were preincubated for $30 \mathrm{~min}$ at $37^{\circ} \mathrm{C}$ in $\mathrm{KRB}$ buffer supplemented with 10 $\mathrm{mM}$ HEPES (KRBH buffer) and $2.8 \mathrm{mM}$ glucose. The cells were then incubated in KRBH buffer supplemented with indicated stimuli for $30 \mathrm{~min}$ unless otherwise indicated. When inhibitors were used, they were added $30 \mathrm{~min}$ before the stimuli. Insulin in the media was measured by rat insulin ELISA kit (Mercodia, Sweden).

\section{PKC translocation and western blotting assays}

After preincubation in KRBH buffer containing $2.8 \mathrm{mM}$ glucose for $1 \mathrm{~h}$, INS-1E cells were stimulated with indicated compounds. The cells were fractionated following the protocol described previously [5]. Briefly, the cells were scraped with cold homogenization buffer (10 mM Tris, $\mathrm{pH}$ 7.4, $4.5 \mathrm{mM}$ EDTA, 2.5 mM EGTA, $2.3 \mathrm{mM} \beta$-mercaptoethanol and protease inhibitors cocktail (Sigma)) and sonicated on ice. The resulting homogenate was centrifuged at $100000 \times \mathrm{g}$ for $30 \mathrm{~min}$ to separate the cytosolic fraction from the particular fraction. The pellet was briefly sonicated in homogenization buffer containing $0.5 \%$ Triton X-100 and extracted for $30 \mathrm{~min}$ at $4{ }^{\circ} \mathrm{C}$. The resulting homogenate was centrifuged at $16000 \times \mathrm{g}$ for $10 \mathrm{~min}$, and the supernatants were taken as membrane fraction. Equal volume of each sample was subjected to western blotting using indicated antibodies, and signals were detected with Immobilon chemiluminescent HRP substrate (Millipore).

\section{Membrane potential analysis}

Cell membrane potential was monitored using $2 \mu \mathrm{M}$ of the fluorescent probe $\operatorname{DiBAC}_{4}(3)$ (Dojindo) in thermostated $\left(37^{\circ} \mathrm{C}\right)$ plate reader fluorimeter (Berthold Technologies). Filters used for excitation and emission were $485 \mathrm{~nm}$ and $535 \mathrm{~nm}$, respectively. Gö6976 was added $30 \mathrm{~min}$ before the time lapse reading.

\section{Statistics}

Statistical analysis was performed using Sigmaplot and Microsoft Excel software. The level of significance for the difference between data sets was assessed using Student's $t$-test.

\section{Acknowledgments}

We thank J Lippincott-Schwartz (National Institutes of Health, Bethesda, USA) for providing the p58-YFP plasmid; CB Wollheim and P Maechler (University Medical Center, Switzerland) for providing INS-1E cells; W Zawalich (Yale University School of Nursing, USA) for providing islets perifusion devices; Q Song (Institute of Neuroscience, CAS, China) for help in preparing samples for electron microscopy; N Danial (Harvard Medical School, USA) and A Toker (Beth Israel Deaconess Medical Center, USA) for critical reading of the manuscript and helpful suggestions. This work was supported in part by the "973 Program" (2006CB503900, 2006CB910703), and grants from the National Natural Science Foundation of China (\#30821065), the Knowledge Innovation Program of the Chinese Academy of Sciences (KSCX1-YW-02, KJCX2-YW-M15; to JRW), the National Institute on Aging (US) (R37 AG012859; to JY) and the Ministry of Science \& Technology (2009ZX09501-009; to DM). The authors declare no competing financial interests.

\section{References}

1 Straub SG, Sharp GW. Glucose-stimulated signaling pathways in biphasic insulin secretion. Diabetes Metab Res Rev 2002; 18:451-463.

2 Henquin JC. Triggering and amplifying pathways of regulation of insulin secretion by glucose. Diabetes 2000; 49:17511760 .

3 Henquin JC. Pathways in $\beta$-cell stimulus-secretion coupling as targets for therapeutic insulin secretagogues. Diabetes 2004; 53 Suppl 3:S48-S58.

4 Gembal M, Detimary P, Gilon P, Gao ZY, Henquin JC. Mechanisms by which glucose can control insulin release independently from its action on adenosine triphosphate-sensitive $\mathrm{K}^{+}$ channels in mouse B cells. J Clin Invest 1993; 91:871-880.

5 Knutson KL, Hoenig M. Identification and subcellular characterization of protein kinase-C isoforms in insulinoma $\beta$-cells and whole islets. Endocrinology 1994; 135:881-886.

6 Zawalich WS, Zawalich KC. Effects of protein kinase C inhibitors on insulin secretory responses from rodent pancreatic islets. Mol Cell Endocrinol 2001; 177:95-105.

7 Uchida T, Iwashita N, Ohara-Imaizumi M, et al. Protein kinase $\mathrm{C} \delta$ plays a non-redundant role in insulin secretion in pancreatic $\beta$ cells. J Biol Chem 2007; 282:2707-2716.

8 Mendez CF, Leibiger IB, Leibiger B, et al. Rapid association of protein kinase $\mathrm{C}-\varepsilon$ with insulin granules is essential for insulin exocytosis. J Biol Chem 2003; 278:44753-44757.

9 Warwar N, Efendic S, Ostenson CG, Haber EP, Cerasi E, Nesher R. Dynamics of glucose-induced localization of PKC isoenzymes in pancreatic $\beta$-cells: diabetes-related changes in the GK rat. Diabetes 2006; 55:590-599.

10 Yedovitzky M, Mochly-Rosen D, Johnson JA, et al. Translocation inhibitors define specificity of protein kinase $\mathrm{C}$ isoenzymes in pancreatic $\beta$-cells. J Biol Chem 1997; 272:1417- 
1420.

11 Pan $\mathrm{H}$, Yu J, Zhang L, et al. A novel small molecule regulator of guanine nucleotide exchange activity of the ADP-ribosylation factor and golgi membrane trafficking. $\mathrm{J}$ Biol Chem 2008; 283:31087-31096.

12 Hauri HP, Kappeler F, Andersson H, Appenzeller C. ERGIC53 and traffic in the secretory pathway. J Cell Sci 2000; 113:587-596.

13 Ma D, Zhang T, Wang G, Kozikowski AP, Lewin NE, Blumberg PM. Synthesis of 7,8-disubstituted benzolactam-V8 and its binding to protein kinase C. Bioorg Med Chem Lett 2001; 11:99-101.

14 Ma D, Tang G, Kozikowski AP. Synthesis of 7-substituted benzolactam-V8s and their selectivity for protein kinase C isozymes. Org Lett 2002; 4:2377-2380.

15 Nakamura N, Rabouille C, Watson R, et al. Characterization of a cis-Golgi matrix protein, GM130. J Cell Biol 1995; 131:1715-1726.

16 Sullivan BM, Harrison-Lavoie KJ, Marshansky V, et al. RGS4 and RGS2 bind coatomer and inhibit COPI association with Golgi membranes and intracellular transport. Mol Biol Cell 2000; 11:3155-3168.

17 Warner CL, Stewart A, Luzio JP, et al. Loss of myosin VI reduces secretion and the size of the Golgi in fibroblasts from Snell's waltzer mice. EMBO J 2003; 22:569-579.

18 Blackshear PJ. The MARCKS family of cellular protein kinase C substrates. J Biol Chem 1993; 268:1501-1504.

19 Steinberg SF. Structural basis of protein kinase C isoform function. Physiol Rev 2008; 88:1341-1378.

20 Gould CM, Newton AC. The life and death of protein kinase C. Curr Drug Targets 2008; 9:614-625.

21 Newton AC. Protein kinase C: structure, function, and regulation. J Biol Chem 1995; 270:28495-28498.

22 Gembal M, Gilon P, Henquin JC. Evidence that glucose can control insulin release independently from its action on ATPsensitive $\mathrm{K}^{+}$channels in mouse B cells. J Clin Invest 1992; 89:1288-1295.

23 Zawalich WS, Zawalich KC. Species differences in the induction of time-dependent potentiation of insulin secretion. Endocrinology 1996; 137:1664-1669.

24 Carpenter L, Mitchell CJ, Xu ZZ, Poronnik P, Both GW, Biden TJ. PKC $\alpha$ is activated but not required during glucoseinduced insulin secretion from rat pancreatic islets. Diabetes 2004; 53:53-60.

25 Schmitz-Peiffer C, Laybutt DR, Burchfield JG, et al. Inhibition of PKC $\varepsilon$ improves glucose-stimulated insulin secretion and reduces insulin clearance. Cell Metab 2007; 6:320-328.

26 Cantley J, Burchfield JG, Pearson GL, Schmitz-Peiffer C,
Leitges M, Biden TJ. Deletion of PKCE selectively enhances the amplifying pathways of glucose-stimulated insulin secretion via increased lipolysis in mouse $\beta$-cells. Diabetes 2009; 58:1826-1834.

27 Rose T, Efendic S, Rupnik M. $\mathrm{Ca}^{2+}$-secretion coupling is impaired in diabetic Goto Kakizaki rats. J Gen Physiol 2007; 129:493-508.

28 Bisbis S, Bailbe D, Tormo MA, et al. Insulin resistance in the GK rat: decreased receptor number but normal kinase activity in liver. Am J Physiol 1993; 265:E807-813.

29 Griffin ME, Marcucci MJ, Cline GW, et al. Free fatty acidinduced insulin resistance is associated with activation of protein kinase $\mathrm{C}$ theta and alterations in the insulin signaling cascade. Diabetes 1999; 48:1270-1274.

30 Schmitz-Peiffer C, Browne CL, Oakes ND, et al. Alterations in the expression and cellular localization of protein kinase $\mathrm{C}$ isozymes epsilon and theta are associated with insulin resistance in skeletal muscle of the high-fat-fed rat. Diabetes 1997; 46:169-178.

31 Itani SI, Ruderman NB, Schmieder F, Boden G. Lipidinduced insulin resistance in human muscle is associated with changes in diacylglycerol, protein kinase C, and IkappaBalpha. Diabetes 2002; 51:2005-2011.

32 Yu C, Chen Y, Cline GW, et al. Mechanism by which fatty acids inhibit insulin activation of insulin receptor substrate-1 (IRS-1)-associated phosphatidylinositol 3-kinase activity in muscle. J Biol Chem 2002; 277:50230-50236.

33 Dey D, Basu D, Roy SS, Bandyopadhyay A, Bhattacharya S. Involvement of novel PKC isoforms in FFA induced defects in insulin signaling. Mol Cell Endocrinol 2006; 246:60-64.

34 Mack E, Ziv E, Reuveni H, et al. Prevention of insulin resistance and beta-cell loss by abrogating PKC 8 -induced serine phosphorylation of muscle IRS-1 in Psammomys obesus. Diabetes Metab Res Rev 2008; 24:577-584.

35 Merglen A, Theander S, Rubi B, Chaffard G, Wollheim CB, Maechler P. Glucose sensitivity and metabolism-secretion coupling studied during two-year continuous culture in INS1E insulinoma cells. Endocrinology 2004; 145:667-678.

36 Zhang L, Yu J, Pan H, et al. Small molecule regulators of autophagy identified by an image-based high-throughput screen. Proc Natl Acad Sci USA 2007; 104:19023-19028.

37 Lacy PE, Kostianovsky M. Method for the isolation of intact islets of Langerhans from the rat pancreas. Diabetes 1967; 16:35-39.

38 Lacy PE, Walker MM, Fink CJ. Perifusion of isolated rat islets in vitro. Participation of the microtubular system in the biphasic release of insulin. Diabetes 1972; 21:987-998.

(Supplementary information is linked to the online version of the paper on the Cell Research website.) 